\title{
Emission Characteristics of Formaldehyde and Particulate Matter in Side-Stream Smoke Emitted from Cigarettes in an Environmental Chamber
}

\author{
Peiyong Ni, Ziheng Zhang, Haiyan Xu, Xuewen Zhang* \\ School of Mechanical Engineering, Nantong University, Nantong 226019, China
}

Received: 7 June 2021

Accepted: 30 August 2021

\begin{abstract}
Side-stream smoke from cigarettes contains formaldehyde, inhalable particulate matter and other pollutants, which seriously affects human health. The formaldehyde and inhalable particles in sidestream smoke emitted from four common brands of cigarettes in an environmental chamber were monitored by using a hand-held formaldehyde detector and a particulate detector. The concentration of the pollutants was also studied under conditions of closeness, natural ventilation and mechanical ventilation. The results show that the burning rates of four brands of cigarettes range from 2.65 to $3.0 \mathrm{~g} / \mathrm{h}$ in the enclosed environment chamber and the peak concentrations of formaldehyde emissions range from 1.02 to $1.72 \mathrm{mg} / \mathrm{m}^{3}$. The release process of particulate matter can be divided into release diffusion stage and sedimentation stage. The peak concentrations of $\mathrm{PM}_{2.5}$ and $\mathrm{PM}_{10}$ is 0.282 and $3.382 \mathrm{mg} / \mathrm{m}^{3}$, respectively. The sedimentation rates of $\mathrm{PM}_{2.5}$ and $\mathrm{PM}_{10}$ are 0.0180 and $0.0289 \mathrm{mg} / \mathrm{m}^{3} \cdot \mathrm{h}^{-1}$, respectively. It is found that the removal rate of formaldehyde and particulate matter is positively correlated with the ventilation rate. The fitting correlation coefficients of formaldehyde concentration during the rise and fall phases under closed conditions are greater than 0.968 and 0.979 , respectively, and the coefficients of $\mathrm{PM}_{2.5}$ and $\mathrm{PM}_{10}$ are greater than 0.904 and 0.929 , respectively.
\end{abstract}

Keywords: formaldehyde, fine particles, side-stream smoke, environmental chamber

\section{Introduction}

Formaldehyde and particulate matter are the two most common air pollutants. Indoor formaldehyde mainly comes from decoration paint, furniture board

e-mail: zhangxuewen@ntu.edu.cn
[1]. They can cause a series of diseases such as red cell deformation [2], chronic respiratory diseases, fetal malformation, leukemia and nasopharyngeal cancer. Formaldehyde is classified as a carcinogen by the International Agency for Research on Cancer [3-5]. There are many sources of particulate matter, coal-fired power plants [6], heavy industrial production [7] and the use of fuel vehicles [2], can emit a lot of particulate matter. Particulate pollution can also harm human 
health, and the degree of harm is mainly affected by particle size, concentration and composition [8, 9]. Particulate matter is divided into inhalable particulate matter (particle size $\leq 10 \mu \mathrm{m}, \mathrm{PM}_{10}$ ), fine particulate matter (particle size $\leq 2.5 \mu \mathrm{m}, \mathrm{PM}_{2.5}$ ) and ultra-fine particulate matter (particle size $\leq 0.1 \mu \mathrm{m}$, UFPS, close to the particle size of the virus [10]). Studies have shown that smaller particles do greater harm to human health [11-13].

Cigarette smoke is one of the main pollution sources that affect indoor air quality and harm human health [14, 15], it is mainly divided into mainstream smoke and side-stream smoke. The mainstream smoke refers to the smoke inhaled by smokers through the filter, while the side-stream smoke refers to the smoke released by the cigarette end when the cigarette is burned [16]. The smoke emitted by a cigarette contains more than 4000 toxic substances, including more than 3800 substances harmful to human health, such as formaldehyde, fine particles [17], polycyclic aromatic hydrocarbons (PAHs) [18], heavy metals due to soil and water problems in tobacco growing areas [19, 20]. Many studies on detection of ingredients from cigarette smoke have been carried out. Some scholars determined formaldehyde by optimizing deoxygenant method and evaluated the temperature dependence of formaldehyde distribution in cigarette mass spectrometry. Inhaling formaldehyde from cigarette smoke had a great risk of genotoxicity [21]. Small particles from tobacco products were quite harmful [22]. Formaldehyde in human saliva was used as an indicator of environmental tobacco smoke exposure. Smoking had a significant effect on formaldehyde content in saliva [23].

Obviously, the characteristics of mainstream smoke or the pathological effects of cigarette smoke were focused [24], but it is not enough research in measurement smoke flow. Nicotine, tar content and other parameters on cigarette case are labelled, but the emission characteristics data of harmful components such as formaldehyde and particulate matter in sidestream smoke are missing. It is worth considering whether the different manufacturing process and additives will affect the emission characteristics of smoke pollutants. In addition, how to reduce or remove the pollution of cigarette smoke also needs to be studied.

To explore the above problems, four brands of cigarettes in the market were selected, and their production process, tar content and other parameters are different. In the closed conditions, the emissions of formaldehyde and particulate matter were measured. At the same time, the effect of ventilation on particles from cigarettes was also investigated.

\section{Materials and Methods}

\section{Test Devices}

The test was performed in an environmental chamber with the volume of $1 \mathrm{~m}^{3}$, as shown in Fig. 1 . As a cigarette placement point, a cylinder with a height of $0.6 \mathrm{~m}$ (including the thickness of the circular tray) was erected on the bottom of the chamber. A monitoring equipment placement place was set on the wall with a height of $0.6 \mathrm{~m}$ (including the thickness of the bracket) opposite to the cigarette placement point. The distance from the center of the round tray of the burning point to the center of the placing board of the monitoring equipment was $0.8 \mathrm{~m}$. In addition, two vents of with length and width of $130 \mathrm{~mm}$ and $130 \mathrm{~mm}$ were installed on both sides of the wall of the chamber. A pipe of each fan extended to one side of the vent and two baffles for closures were set on both sides of the vents.

In this study, four common brands of cigarettes on the market were tested. The basic parameters of the cigarettes are shown in Table 1.

A $\mathrm{PC}-3 \mathrm{~A}(\mathrm{~S})$ type dust detector with a sensitivity of $0.001 \mathrm{mg} / \mathrm{m}^{3}$ was used to measure $\mathrm{PM}_{2.5}$ and $\mathrm{PM}_{10}$ concentrations. The detection ranges for $\mathrm{PM}_{2.5}$ and $\mathrm{PM}_{10}$ are $0 \sim 10 \mathrm{mg} / \mathrm{m}^{3}$ and $0 \sim 20 \mathrm{mg} / \mathrm{m}^{3}$, respectively. A HTV-M type detector was used to measure the concentration of formaldehyde. It has a detection
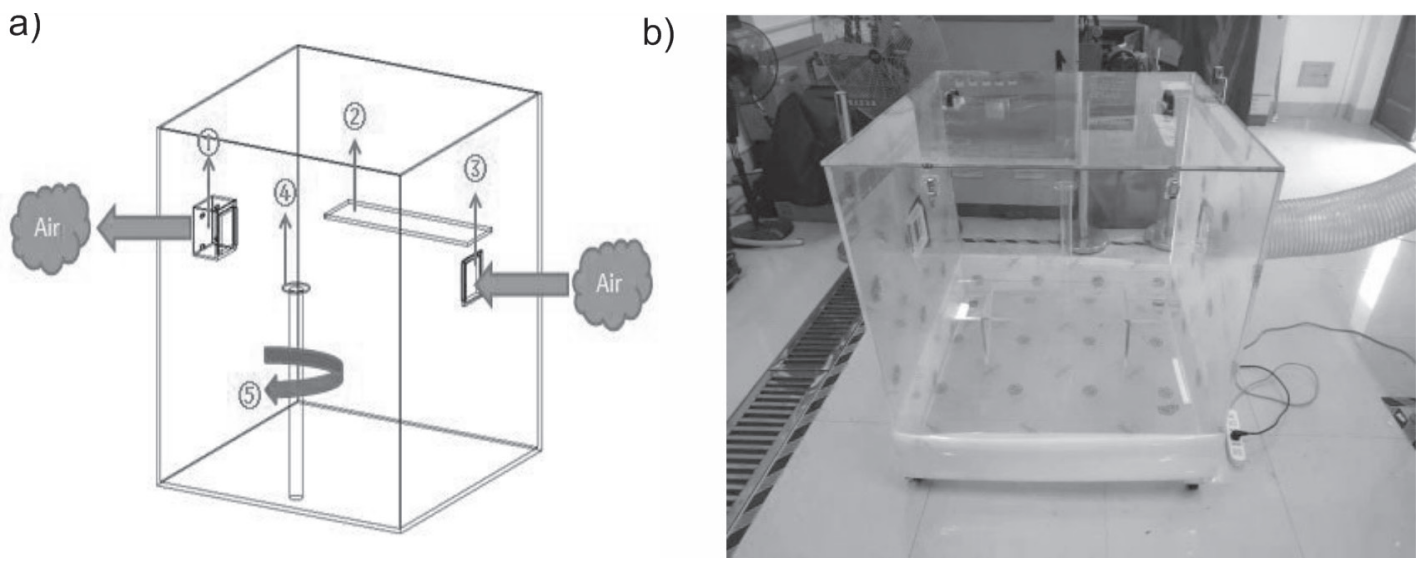

Fig. 1. Tested environmental chamber a) 3D drawing: (1) Fan vent, (2) Instrument, (3) Vent, (4) Cigarette tray, (5) Cylinde, b) Physical picture. 
Table 1. Basic parameters of the tested cigarettes.

\begin{tabular}{|c|c|c|c|c|}
\hline Cigarette brands & Cigarette types & Tar/mg & Nicotine content in smoke $/ \mathrm{mg}$ & Flue gas - carbon monoxide $/ \mathrm{mg}$ \\
\hline A & Flue-cured & 11 & 1.0 & 13 \\
\hline B & Flue-cured & 11 & 1.0 & 11 \\
\hline C & Flue-cured & 8 & 0.8 & 10 \\
\hline D & Blended & 8 & 0.7 & 9 \\
\hline
\end{tabular}

sensitivity of $0.001 \mathrm{mg} / \mathrm{m}^{3}$ and a detection range of $0 \sim 12.3 \mathrm{mg} / \mathrm{m}^{3}$. A blower was used for air exchange in the chamber. The blower has an air flow of $1.15 \mathrm{~m}^{3} / \mathrm{min}$ at the rated speed of $2000 \mathrm{r} / \mathrm{min}$.

\section{Experimental Procedure}

During the test process, the indoor temperature was set to $16 \pm 2^{\circ} \mathrm{C}$, and relative humidity to $35 \pm 5 \%$. The two vents were opened under natural ventilation condition. The air flow of the blower was $1.15 \mathrm{~m}^{3} / \mathrm{min}$ under mechanical ventilated condition. The tested cigarette was put on the cylinder with a height of $0.6 \mathrm{~m}$ [25]. According to the average social distance [26], the distance from the detectors to the cigarette in the horizontal direction was $0.8 \mathrm{~m}$. After the cigarette was lit, the detectors started to record the emission data. The monitoring time was from 200 to 600 minutes under closed conditions. The monitoring time was 192 minutes under nature and mechanical ventilation conditions.

\section{Characteristic Parameters}

During cigarette combustion, according to the law of conservation of mass, Equation (1) is established, which is often used to analyze the distribution and migration of indoor and outdoor particulate matter [27, 28].

$$
\frac{d C_{I N}}{d t}=P \alpha C_{\text {OUT }}+\frac{E r}{V}-\left(\alpha+\lambda_{S I N K}\right) C_{I N}
$$

where $C_{I N}$ is the concentration of particulate matter in the environmental chamber $\left(\mathrm{mg} / \mathrm{m}^{3}\right), P$ is the penetration coefficient, $\alpha$ is air exchange rate $(1 / \mathrm{h}), C_{\text {OUT }}$ is the concentration of particulate matter outside the environment chamber $\left(\mathrm{mg} / \mathrm{m}^{3}\right), E r$ is the quantitative release rate $(\mathrm{mg} / \mathrm{h}), V$ is the volume in the environment chamber $\left(\mathrm{m}^{3}\right)$ and $\lambda_{\text {SINK }}$ is the deposition rate of particulate matter $\left(\mathrm{mg} / \mathrm{m}^{3} \cdot \mathrm{h}^{-1}\right)$.

Because the environmental chamber with adhesive strips at the cracks has good sealing performance, the particle penetration is ignored. Therefore, Equation (1) can be rewritten as:

$$
\lambda_{S I N K}=\frac{1}{t} \ln \frac{C_{M A X}-C_{0}}{C_{t}-C_{0}}-\alpha
$$

...where $C_{0}$ is the background concentration in the $(\mathrm{mg} /$ $\mathrm{m}^{3}$ ) and $C_{t}$ is the concentration in the chamber at $t$ time $\left(\mathrm{mg} / \mathrm{m}^{3}\right)$.

Assuming that the bottom concentration in the environmental chamber is zero, Equations (1) and (2) can be further deduced:

$$
\begin{gathered}
C_{I N}=\frac{\operatorname{Er}\left(1-e^{-k t}\right)}{V k}(0 \leq t \leq T) \\
C_{I N}=C_{\text {MAX }}\left(e^{-k(t-T)}\right)(T>t) \\
k=\alpha+\lambda_{\text {SINK }}
\end{gathered}
$$

where $k$ is the particle removal rate $(\mathrm{mg} / \mathrm{h}) . T$ is the burning time of cigarette (h) and $C_{M A X}$ is the maximum concentration $\left(\mathrm{mg} / \mathrm{m}^{3}\right)$.

The emission rate of particulate matter and formaldehyde can be given by:

$$
E r=\frac{C_{M A X} \alpha V}{1-e^{-\alpha T}}
$$

The burning rate of the cigarettes is written as:

$$
B r=\frac{M}{T}
$$

where $M$ is the weight of the tested cigarettes $(\mathrm{g})$.

The particulate matter and formaldehyde emission factors are presented as:

$$
E f=\frac{E r}{B r}
$$

where $E f$ is the emission factor $(\mathrm{mg} / \mathrm{g})$.

\section{Results and Discussion}

Emission Characteristics of Formaldehyde and Particulate Matter under Closed Conditions

Table 2 shows the combustion characteristics of four kinds of cigarettes under closed conditions. It is 
Table 2. Combustion characteristics of four kinds of cigarettes under closed condition.

\begin{tabular}{|c|c|c|c|c|c|}
\hline Cigarette brands & $\begin{array}{c}\text { Cigarette burning } \\
\text { rate }(\mathrm{g} / \mathrm{h})\end{array}$ & $\begin{array}{c}\text { Pre-combustion } \\
\text { mass/g }\end{array}$ & $\begin{array}{c}\text { Post-combustion } \\
\text { mass/g }\end{array}$ & $\begin{array}{c}\text { Combustion } \\
\text { quality/g }\end{array}$ & Burning time/min \\
\hline $\mathrm{A}$ & 3.000 & 0.64 & 0.09 & 0.55 & 11 \\
\hline $\mathrm{B}$ & 2.800 & 0.62 & 0.06 & 0.56 & 12 \\
\hline $\mathrm{C}$ & 2.782 & 0.63 & 0.12 & 0.51 & 11 \\
\hline $\mathrm{D}$ & 2.650 & 0.66 & 0.13 & 0.53 & 12 \\
\hline
\end{tabular}

found that the burning rate of cigarettes range from 2.650 to $3.000 \mathrm{~g} / \mathrm{h}$. The burning rate of each cigarette is related to its own characteristics. Combined with the basic characteristic data of cigarettes in Table 1, the burning rate of cigarettes is positively correlated with the amount of carbon monoxide in the smoke. When the burning rate of the cigarette becomes fast, the cut tobacco burns incompletely. As a result, the carbon monoxide content in the smoke increases.

The curves of formaldehyde concentration in the side-stream smoke of four kinds of cigarettes are shown in Fig. 2. Table 3 shows the peak concentration, emission rates and emission factors of formaldehyde for the four kinds of cigarettes under closed conditions. The peak concentration of formaldehyde ranges

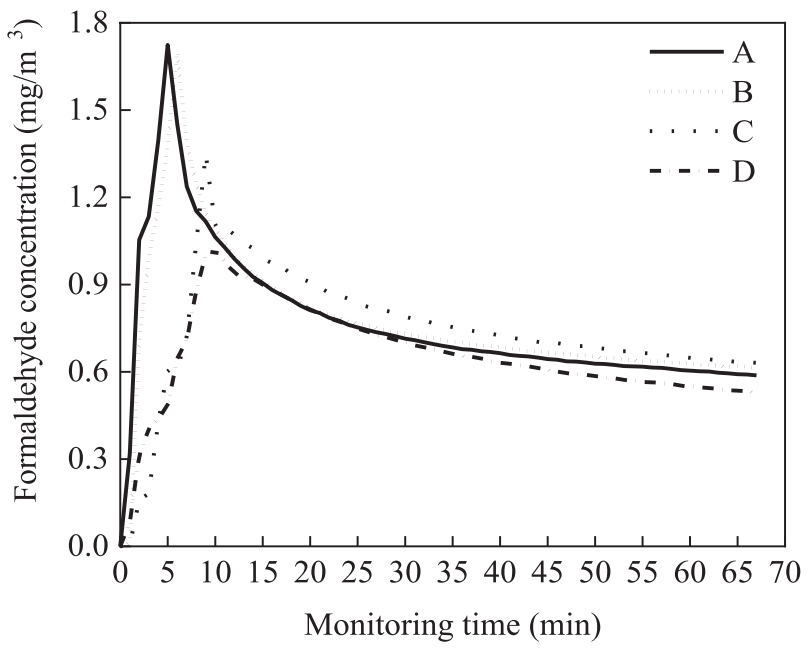

Fig. 2. Formaldehyde concentrations of four kinds of cigarettes under closed condition. from 1.022 to $1.724 \mathrm{mg} / \mathrm{m}^{3}$. After about 15 minutes, formaldehyde concentration for cigarette A reaches its peak. However, for cigarette $\mathrm{C}$ and $\mathrm{D}$, the peaks of formaldehyde concentration occur after 30 minutes. The order of formaldehyde emission factors of four kinds of cigarettes is A, B, C and D. During the combustion stage, the formaldehyde concentration rises to a peak value rapidly. However, after the cigarette is burned out, the concentration of the formaldehyde decreases slowly due to gas leaks.

Fig. 3 presents the particulate matter concentration of four kinds of cigarettes. Table 4 shows the statistical characteristics of particulate matter of four kinds of cigarettes. It can be seen that the peak concentration of $\mathrm{PM}_{2.5}$ and $\mathrm{PM}_{10}$ are in the range of 0.272 to $0.282 \mathrm{mg} / \mathrm{m}^{3}$ and 3.294 to $3.455 \mathrm{mg} / \mathrm{m}^{3}$. In addition, the $\mathrm{PM}_{2.5}$ concentration trend is basically the same. However, the $\mathrm{PM}_{2.5}$ concentrations of cigarette $\mathrm{A}$ and $\mathrm{D}$ are significantly higher than those of cigarette B and $\mathrm{C}$ after about 15 minutes, and the highest concentration difference between cigarette $\mathrm{B}$ and cigarette $D$ is $0.564 \mathrm{mg} / \mathrm{m}^{3}$. Obviously, the peak concentration of $\mathrm{PM}_{2.5}$ of cigarette $\mathrm{D}$ is the lowest, while the peak concentration of $\mathrm{PM}_{10}$ of cigarette D is the highest. It is also found that the concentrations of particulate matter of the four kinds of cigarettes increase rapidly during combustion stage. However, the concentrations of particulate matter remain at high level for a long time after the cigarette is burned out. The reason is that the environmental chamber has a good sealing performance. In addition, the concentrations of $\mathrm{PM}_{10}$ of the four kinds of cigarettes are much higher than those of $\mathrm{PM}_{2.5}$. It can be seen that the emission rates of $\mathrm{PM}_{2.5}$ and $\mathrm{PM}_{10}$ of the four kinds of cigarettes range from 1.506 to $1.684 \mathrm{mg} / \mathrm{h}$ and from 18.834 to $20.190 \mathrm{mg} / \mathrm{h}$.

Table 3. Formaldehyde emission characteristics of four kinds of cigarettes under closed condition.

\begin{tabular}{|c|c|c|c|}
\hline $\begin{array}{c}\text { Cigarette } \\
\text { brands }\end{array}$ & $\begin{array}{c}\text { Peak concentration of formaldehyde } \\
\left(\mathrm{mg} / \mathrm{m}^{3}\right)\end{array}$ & $\begin{array}{c}\text { Rate of formaldehyde emission } \\
(\mathrm{mg} / \mathrm{h})\end{array}$ & $\begin{array}{c}\text { Formaldehyde emission factor } \\
(\mathrm{mg} / \mathrm{g})\end{array}$ \\
\hline A & 1.724 & 10.292 & 3.431 \\
\hline B & 1.699 & 9.373 & 3.347 \\
\hline C & 1.349 & 8.053 & 2.895 \\
\hline D & 1.022 & 5.638 & 2.128 \\
\hline
\end{tabular}



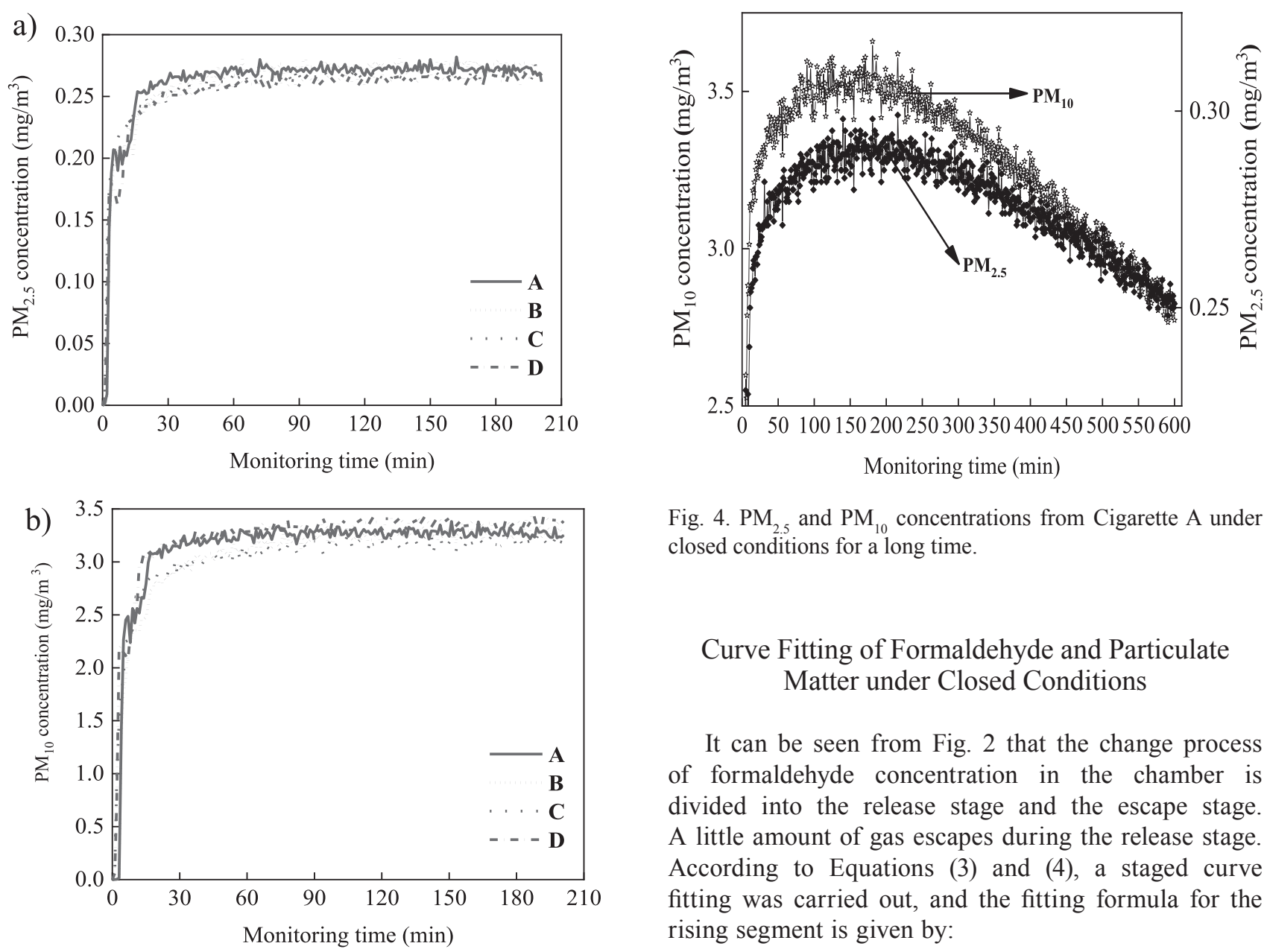

Fig. 4. $\mathrm{PM}_{2.5}$ and $\mathrm{PM}_{10}$ concentrations from Cigarette A under closed conditions for a long time.

\section{Curve Fitting of Formaldehyde and Particulate Matter under Closed Conditions}

It can be seen from Fig. 2 that the change process of formaldehyde concentration in the chamber is divided into the release stage and the escape stage. A little amount of gas escapes during the release stage. According to Equations (3) and (4), a staged curve fitting was carried out, and the fitting formula for the rising segment is given by:

$$
y=a(1-\exp (-b x))
$$

under closed conditions: a) $\mathrm{PM}_{2.5}$, b) $\mathrm{PM}_{10}$.

To study the deposition of particulate matter, a longer test for cigarette A was conducted under closed conditions, and the duration of the experiment was extended to $10 \mathrm{~h}$. The emission curve of particulate matter is shown in Fig. 4. It can be seen that the concentration of $\mathrm{PM}_{2.5}$ decreases more slowly than that of $\mathrm{PM}_{10}$. According to Equation (2), the deposition rates of $\mathrm{PM}_{2.5}$ and $\mathrm{PM}_{10}$ are 0.018 and $0.0289 \mathrm{mg} / \mathrm{m}^{3} \cdot \mathrm{h}^{-1}$. This is consistent with the conclusion of the reference [29]. written as:

$$
y=A_{1} \exp \left(-x / t_{1}\right)+y_{0}
$$

The fitting results of formaldehyde concentrations are shown in Fig. 5. The fitting correlation coefficients range from 0.96817 to 0.98017 during the release stage and from 0.97947 to 0.99883 during the escape stage, indicating that the deduced formula is reliable. It can be seen that the fitting result of escape stage is better than that of release stage. The main reason is that the

\begin{tabular}{|c|c|c|c|c|c|c|c|}
\hline \multirow[t]{2}{*}{$\begin{array}{l}\text { Cigarette } \\
\text { brands }\end{array}$} & \multicolumn{2}{|c|}{$\begin{array}{l}\text { Peak concentration } \\
\left(\mathrm{mg} / \mathrm{m}^{3}\right)\end{array}$} & \multirow{2}{*}{$\begin{array}{c}\text { The ratio of } \mathrm{PM}_{2.5} \text { to } \mathrm{PM}_{10} \text { peak } \\
\text { concentration (\%) }\end{array}$} & \multicolumn{2}{|c|}{ Emission rate (mg/h) } & \multicolumn{2}{|c|}{ Emission factor $(\mathrm{mg} / \mathrm{g})$} \\
\hline & $\mathrm{PM}_{2.5}$ & $\mathrm{PM}_{10}$ & & $\mathrm{PM}_{2.5}$ & $\mathrm{PM}_{10}$ & $\mathrm{PM}_{2.5}$ & $\mathrm{PM}_{10}$ \\
\hline A & 0.282 & 3.382 & 8.338 & 1.684 & 20.190 & 0.561 & 6.730 \\
\hline $\mathrm{B}$ & 0.281 & 3.347 & 8.396 & 1.506 & 18.834 & 0.538 & 6.726 \\
\hline $\mathrm{C}$ & 0.276 & 3.294 & 8.379 & 1.648 & 19.665 & 0.591 & 7.056 \\
\hline $\mathrm{D}$ & 0.272 & 3.455 & 7.873 & 1.501 & 19.060 & 0.566 & 7.193 \\
\hline
\end{tabular}

Table 4. Statistical characteristics of particulate matter of four kinds of cigarette particles under closed condition. 
fluctuation in the temperature and humidity affects the diffusion of formaldehyde gas.

Compared with gas, particles are more difficult to escape from the gap in the environmental chamber. The change process of particle concentration in the chamber is divided into the release stage and the deposition stage. During the release stage, particles from cigarettes are endowed with initial kinetic energy by combustion and the deposition effect can be ignored. After a certain time, energy of motion of particles is not enough to
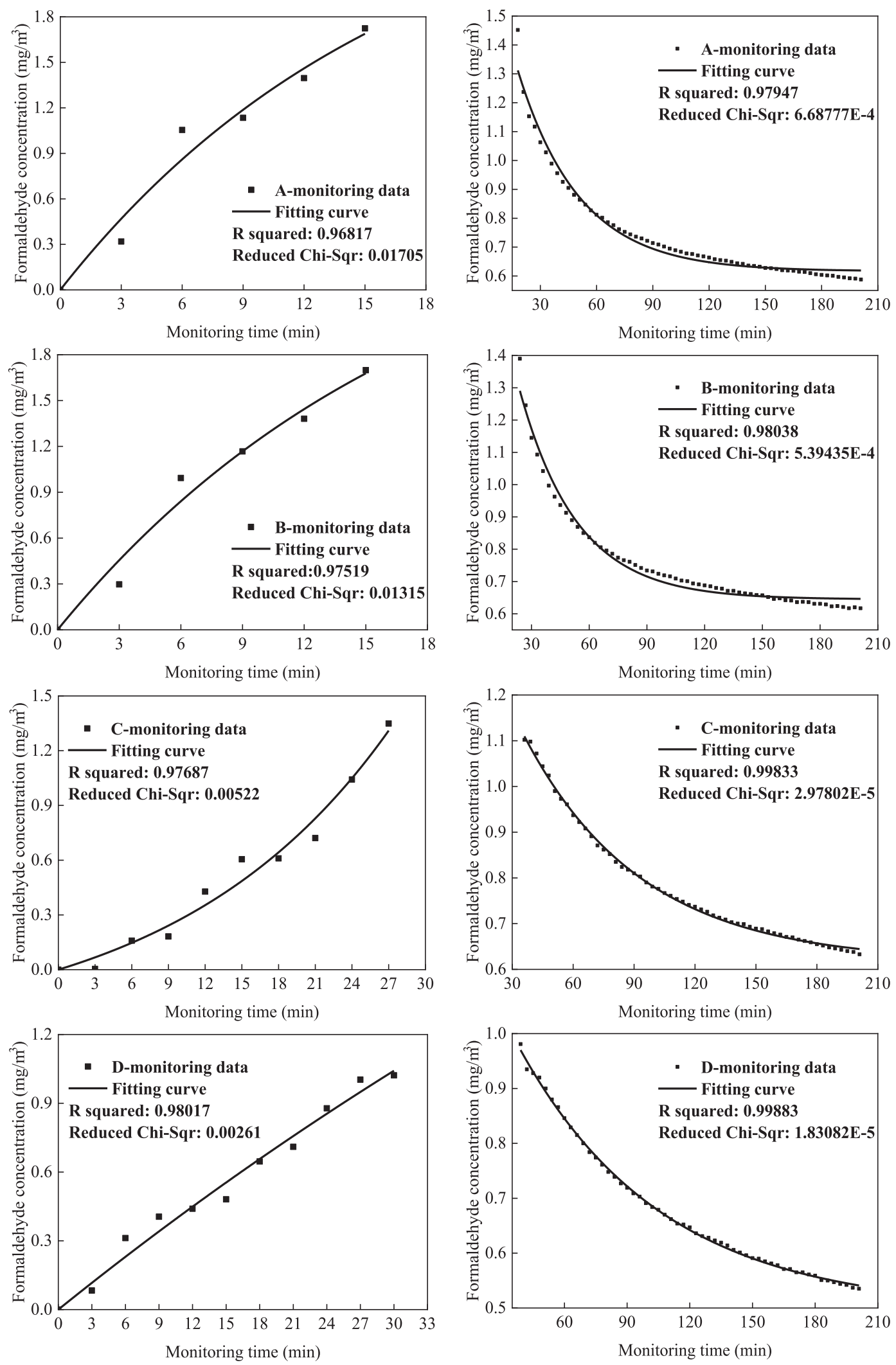

Fig. 5. Fitting of tested formaldehyde concentrations. 
support their continued movement due to energy lose in the collision. Many particles begin to fall due to gravity action during the second stage.

The concentrations of particulate matter keep near the peak value for a long time. Therefore, it is judged
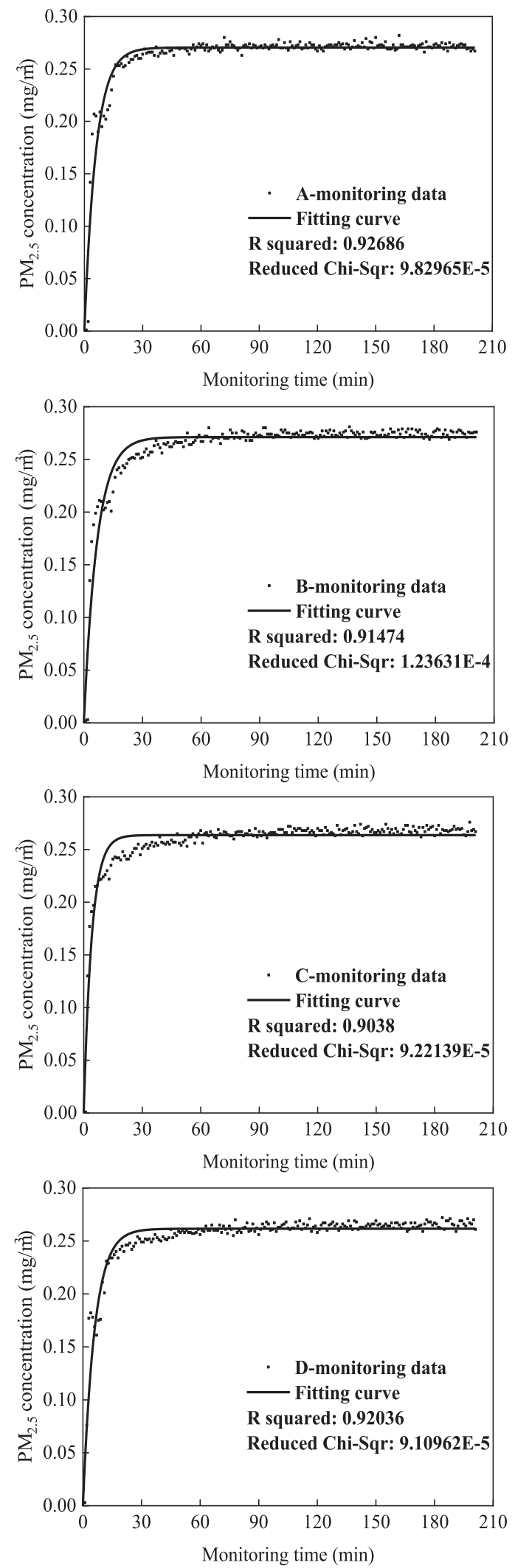

to belong to the release stage. For this stage, the fitting formula is:

$$
y=a(1-\exp (-b x))
$$
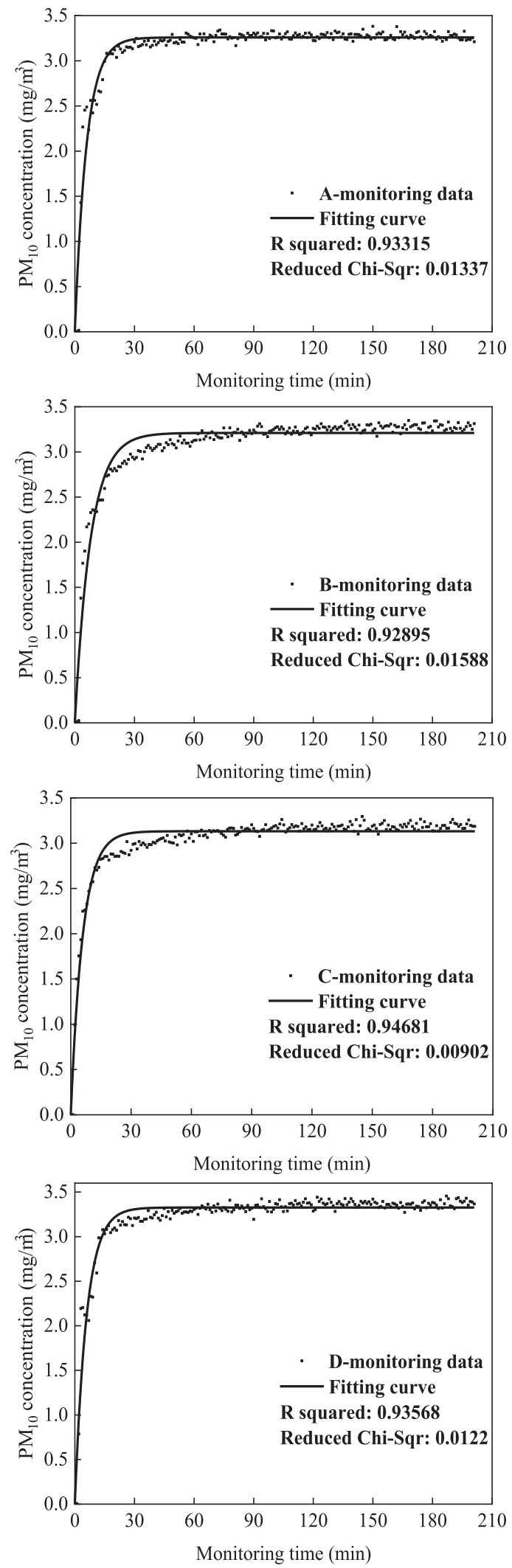

Fig. 6. Fitting of tested particulate concentrations. 


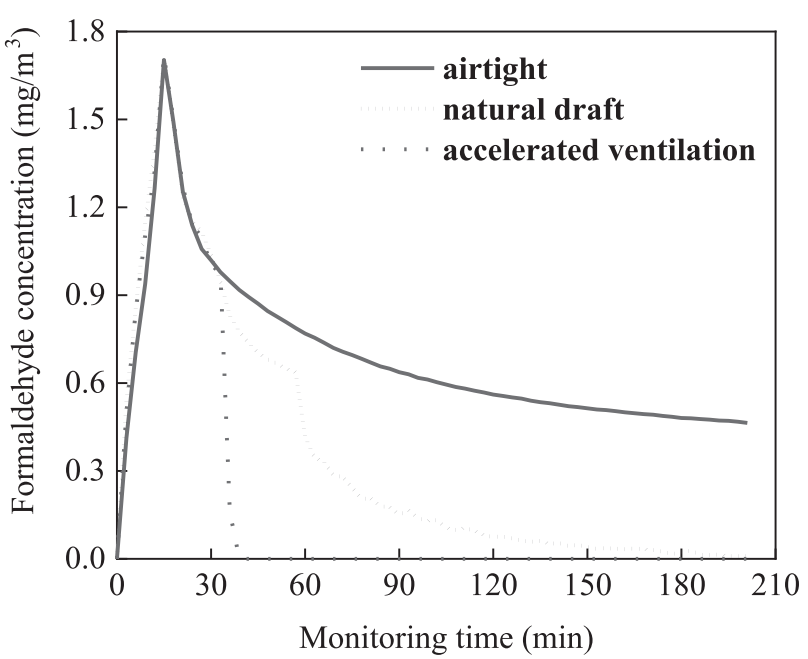

Fig. 7. Formaldehyde concentrations under different ventilation modes.
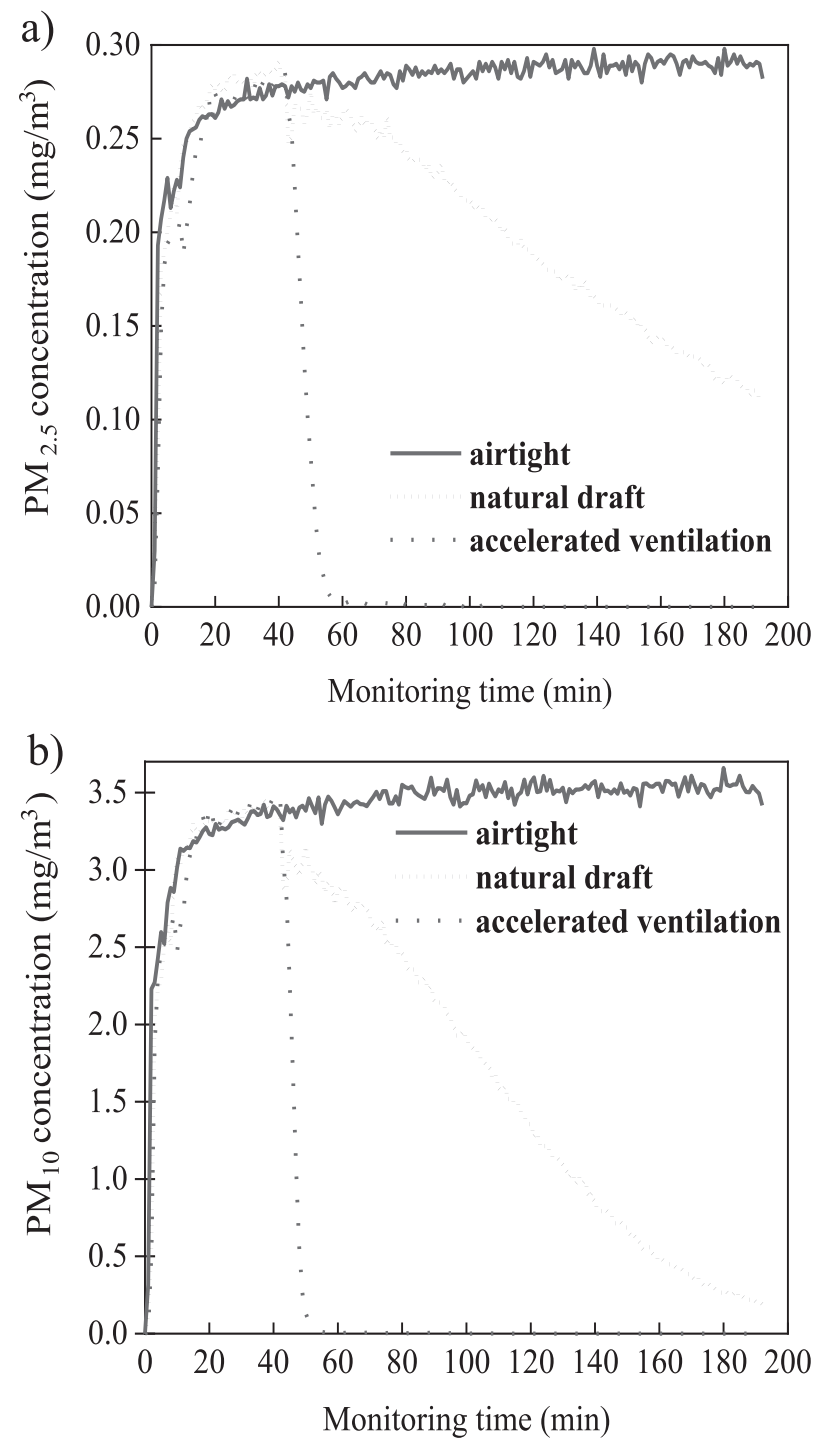

Fig. 8. Concentrations of $\mathrm{PM}_{2.5}$ and $\mathrm{PM}_{10}$ under different ventilation modes: a) $\mathrm{PM}_{2.5}$, b) $\mathrm{PM}_{10}$.
The fitting results of particle concentrations are shown in Fig. 6. It can be seen that the fitting correlation coefficients of $\mathrm{PM}_{2.5}$ and $\mathrm{PM}_{10}$ range from 0.9038 to 0.92686 and ranged from 0.92895 to 0.94681 during the release stage, respectively. Obviously, the performance of linear regression of $\mathrm{PM}_{10}$ is better than that of $\mathrm{PM}_{2.5}$, because gravity has little effect on small particles while other external forces have important effect on them. In addition, the fitting result of particulate matter is worse than that of formaldehyde, especially during the rise period. This reason is that the burning of cigarettes causes drastic changes in the temperature and humidity of the surrounding environment affecting the diffusion and condensation of particulate matter [30-32].

\section{Pollutant Characteristics under Ventilation Conditions}

The concentrations of formaldehyde and particulate matter from A cigarette under ventilation conditions are shown in Figs 7 and 8. It is found that the concentrations of formaldehyde and particulate matter drop rapidly under natural and mechanical ventilation conditions. This proves that ventilation plays a significant role in improving the air quality in the chamber [33]. It is also found that the concentration of $\mathrm{PM}_{2.5}$ decreases more slowly than that of $\mathrm{PM}_{10}$ under ventilated conditions. This reason is that $\mathrm{PM}_{2.5}$ as fine particles are affected by air drag force, adhesion force and levitation force [34, 35].

\section{Conclusions}

When four common brands of cigarettes are burned in a closed environment chamber, they release formaldehyde with a peak concentration of $1.022 \sim 1.724 \mathrm{mg} / \mathrm{m}^{3}, \mathrm{PM}_{25}$ with a peak concentration of $0.265 \sim 0.271 \mathrm{mg} / \mathrm{m}^{3}$ and $\mathrm{PM}_{10}$ with a peak concentration of $3.183 \sim 3.354 \mathrm{mg} / \mathrm{m}^{3}$.

After the cigarettes are burned out, the particle concentrations under closed conditions still keep at high level for a long time, and the particle deposition rate is very small. The removal rate of particulate matter with large particle size is higher than that of particulate matter with small particle size under ventilation conditions.

The fitting of formaldehyde under closed conditions is more reliable. The fitting correlation coefficients of formaldehyde range from 0.96817 to 0.98017 in the release stage and from 0.97947 to 0.99883 in the escape stage, while the fitting correlation coefficients of $\mathrm{PM}_{25}$ and $\mathrm{PM}_{10}$ range from 0.9038 to 0.92686 and ranged from 0.92895 to 0.94681 in the release stage, respectively. 


\section{Acknowledgments}

The authors would like to thank the Priority Academic Program Development of Jiangsu Higher Education Institutions (PAPD) for financial support to this study.

\section{Conflict of Interest}

The authors declare no conflict of interest.

\section{References}

1. SALTHAMMER T. Formaldehyde sources, formaldehyde concentrations and air exchange rates in European housings. Building and Environment, 150, 219, 2019.

2. WARDOY, A.Y.P., JUSWONO U.P., NOOR J.A.E. How Exposure to Ultrafine and Fine Particles of Car Smoke Can Alter Erythrocyte Forms of Male Mice. Polish Journal of Environmental Studies, 28 (4), 2901, 2019.

3. GE J., YANG H.L., LU X.X., WANG S.Q., ZHAO Y., HUANG J.W., XI Z.G., ZHANG L.P., LI R. Combined exposure to formaldehyde and $\mathrm{PM}_{2.5}$ : Hematopoietic toxicity and molecular mechanism in mice. Environment International, 144, 106050, 2020.

4. ZHANG Z.F., ZHANG X., ZHANG X.M., LIU L.Y., LI Y.F., SUN W. Indoor occurrence and health risk of formaldehyde, toluene, xylene and total volatile organic compounds derived from an extensive monitoring campaign in Harbin, a megacity of China. Chemosphere, 250, 126324, 2020.

5. KOSMIDER L., COX S., ZACIERA M., KUREK J., GONIEWICZ M.L., MCROBBIE H., KIMBER C., DAWKINS L. Daily exposure to formaldehyde and acetaldehyde and potential health risk associated with use of high and low nicotine e-liquid concentrations. Scientific Reports, 10 (1), 6546, 2020.

6. WILCZYNSKA-MICHALIK W., DANKO J., MICHALIK M. Characteristics of Particulate Matter Emitted from a Coal-Fired Power Plant. Polish Journal of Environmental Studies, 29 (2), 1411, 2020.

7. JIN X.Y., FAN J.S., NIU H.Y., LING P., YU Q.Q. Analysis of Sources and Concentrations of Heavy Metal Contents in $\mathrm{PM}_{10}$ over a Four-Season Cycle in a Heavily Industrialised City in China. Polish Journal of Environmental Studies, 28 (5), 3227, 2019.

8. ALEMAYEHU Y.A., ASFAW S.L., TERFIE T.A. Exposure to urban particulate matter and its association with human health risks. Environmental Science and Pollution Research, 27 (22), 27491, 2020.

9. KIM I.S., YANG P.S., LEE J., YU H.T., KIM T.H., UHM J.S., KIM J.Y., PAK H.N., LEE M.H., JOUNG B. Longterm fine particulate matter exposure and cardiovascular mortality in the general population: a nationwide cohort study. Journal of Cardiology, 75 (5), 549, 2020.

10. VOSOUGHI M., KARAMI C., DARGAHI A., JEDDI F., JALALI K.M., HADISI A., HAGHIGHI S.B., DOGAHE H.P., NOORIMOTLAGH Z., MIRZAEE S.A. Investigation of SARS-CoV-2 in hospital indoor air of COVID-19 patients'ward with impinger method. Environmental Science and Pollution Research, 10.1007/ s11356-021-14260-3, 2021.
11. PU X.R., WANG L.Y., CHEN L.N., PAN J.P., TANG L., WEN J., QIU H. Differential effects of sizespecific particulate matter on lower respiratory infections in children: A multi-city time-series analysis in Sichuan, China. Environmental Research, 193, 110581, 2021.

12. QIU H., WANG L.Y., ZHOU L., PAN, J.P. Coarse particles $\left(\mathrm{PM}_{25-10}\right)$ and cause-specific hospitalizations in southwestern China: Association, attributable risk and economic costs. Environmental Research, 190, 110004, 2020.

13. SOTTY J., KLUZA J., DE SOUSA C., TARDIVEL M., ANTHERIEU S., ALLEMAN L.Y., CANIVET L., PERDRIX E., LOYENS A., MARCHETTI P., LO GUIDICE J.M., GARCON G.Mitochondrial alterations triggered by repeated exposure to fine $\left(\mathrm{PM}_{2.5-0.18}\right)$ and quasi-ultrafine $\left(\mathrm{PM}_{0.18}\right)$ fractions of ambient particulate matter. Environment International, 142, 105830, 2020.

14. CHEN M.M., CHIU C.H., YUAN C.P., LIAO Y.C., GUO S.E. Influence of Environmental Tobacco Smoke and Air Pollution on Fetal Growth: A Prospective Study. International Journal of Environmental Research and Public Health, 17 (15), 5319, 2020.

15. SINGH A., OKELLO G., SEMPLE S., DOBBIE F., KINNUNEN T.I., LARTEY K.F., LOGO D.D., BAULD L., ANKRAH S.T., MCNEILL A., OWUSU-DABO E. Exposure to secondhand smoke in hospitality settings in Ghana: Evidence of changes since implementation of smoke free legislation. Tobacco Induced Diseases, 18, 44, 2020.

16. CHENG L.C., LIN C.J., LIU H.J., LI L.A. Health risk of metal exposure via inhalation of cigarette sidestream smoke particulate matter. Environment Science And Pollution Research, 26 (11), 10835, 2019.

17. RAJA J., KHOUZAM A., KHOUZAM N., KHOUZAM R.N. Smoke and Heart Should Stay Apart: A Look at E Cigarettes and Other Alternatives to Conventional Cigarettes, and Their Impact on Cardiovascular Health. Current Problems in Cardiology, 46 (3), 100640, 2021.

18. MOKHTARI S.A., GHOLAMI M., DARGAHI A., VOSOUGHI M. Removal of polycyclic aromatic hydrocarbons (PAHs) from contaminated sewage sludge using advanced oxidation process (hydrogen peroxide and sodium persulfate). Desalination and Water Treatment, 213, 311, 2021.

19. ALI A., ABDOLLAH D., MIR M.H.A., HOSNAJANJANI, MITRA M., LEILA T. Efficiency of a constructed wetland in controlling organic pollutants, nitrogen, and heavy metals from sewage. Journal of Chemical and Pharmaceutical Sciences, 9 (4), 2924, 2016.

20. SAMARGHANDI M.R., MOHAMMADI M., KARAMI A., TABANDEH L., DARGAHI A., AMIRIAN F. Residue Analysis of Pesticides, Herbicides, and Fungicides in Various Water Sources Using Gas Chromatography-Mass Detection. Polish Journal of Environmental Studies, 26 (5), 2189, 2017.

21. ZHANG S., CHEN H., ZHANG J.N., LI J., HOU H.W., HU Q.Y. The multiplex interactions and molecular mechanism on genotoxicity induced by formaldehyde and acrolein mixtures on human bronchial epithelial BEAS-2B cells. Environment International, 143, 105943, 2020.

22. MCAULEY T.R., HOPKE P.K., ZHAO J., BABAIAN S. Comparison of the effects of e-cigarette vapor and cigarette smoke on indoor air quality. Inhalation Toxicology, 24 (12), 850, 2012.

23. DEMKOWSKA I., POLKOWSKA Z., NAMIESNIK J. Formaldehyde in Human Saliva as an Indication of 
Environmental Tobacco Smoke Exposure. Polish Journal of Environmental Studies, 19 (3), 573, 2010.

24. LI X., LIN B.C., ZHANG H.S., XIE F.W., TA N., TIAN L., LIU H.M., XI Z.G. Cytotoxicity and mutagenicity of sidestream cigarette smoke particulate matter of different particle sizes. Environmental Science and Pollution Research, 23 (3), 2588, 2016.

25. DONG R.C., HE L., DU W., CAO Z.K., HUANG Z.L. Effect of sitting posture and seat on biodynamic responses of internal human body simulated by finite element modeling of body-seat system. Journal of Sound and Vibration, 438, 543, 2019.

26. RAMSEY C.B. Human agency and infection rates: Implications for social distancing during epidemics. PLOS ONE, 15 (12), e0243699, 2020.

27. DOCKERY D.W., SPENGLER J.D. Indoor-outdoor relationships of respirable sulfates and particles. Atmospheric Environment, 15, 335, 1981.

28. HE C.R., MORAWSKA L.D., HITCHINS J., GILBERT D. Contribution from indoor sources to particle number and mass concentrations in residential houses. Atmospheric Environment, 38 (21), 3405, 2004.

29. SAJJADI H., SALMANZADEH M., AHMADI G., JAFARI S. Simulations of indoor airflow and particle dispersion and deposition by the lattice Boltzmann method using LES and RANS approaches. Building and Environment, 102, 1, 2016.

30. KUGA K., ITO K., YOO S.J., CHEN W.C., WANG P., LIAO J.W., FOWLES J., SHUSTERMAN D., KUMAGAI
K. First- and second-hand smoke dispersion analysis from e-cigarettes using a computer-simulated person with a respiratory tract model. Indoor and Built Environment, 27 (7), 898, 2018.

31. HOLLBACHER E., TERS T., RIEDER-GRADINGER C., SREBOTNIK E. Emissions of indoor air pollutants from six user scenarios in a model room. Atmospheric Environment, 150, 389, 2017.

32. KOOHANDAZ A., KHAVASI E., EYVAZIAN A. YOUSEFI, H. Prediction of particles deposition in a dilute quasi-steady gravity current by Lagrangian markers: effect of shear-induced lift force. Scientific Reports, 10 (1), $16673,2020$.

33. MATTHAIOS V.N., KRAMER L.J., CRILLEY,L.R., SOMMARIVA R., POPE F.D., BLOSS W.J. Quantification of within-vehicle exposure to NOx and particles: Variation with outside air quality, route choice and ventilation options. Atmospheric Environment, 240, 117810, 2020.

34. STONE L., HASTIE D., ZIGAN S. Using a coupled CFD - DPM approach to predict particle settling in a horizontal air stream. Advanced Powder Technology, 30 (4), 869, 2019.

35. HUANG S.H., KANG J.L., WONG D.SH., JANG S.S., LIN C.A. Particle-Scavenging prediction in sieve plate scrubber via dimension reduction in computational fluid dynamics. Chemical Engineering Research and Design, 160, 540, 2020. 